\title{
A thiol-amine mixture for metal oxide towards device quality metal chalcogenides
}

\author{
Tong Zhang, Lijian Zhang, Yiwei Yin, Chenhui Jiang, Shi'ang Li, Changfei Zhu ${ }^{*}$ and Tao Chen
}

Metal chalcogenides (MCs) are significant semiconducting materials possessing a variety of applications in catalysts $[1,2]$, thermoelectrics $[3,4]$, rewritable memory $[5,6]$, thin film transistors (TFTs) $[7,8]$, and solar cells [916], usually presenting as solid films. Until now, one can deposit the bulk materials on a substrate by either topdown method such as thermal evaporation or bottom-up deposition from molecular precursors. The latter approach, usually described as solution processing, allows low-energy, low-cost, high-speed and high-throughput manufacturing, and is compatible with a variety of substrates [17-19]. A key step for the transformation towards final product is to find suitable solvent for dissolving the precursors and the consequent chemical conversion. A successful approach demonstrated by Mitzi and co-workers [12,20-25] utilized hydrazine-based solution with strong coordination and reduction capability to dissolve bulk MCs, forming molecular inks to generate MC films. However, hydrazine is highly toxic, explosive and hazardous, posing potential challenge regarding the scalable application. To find "greener" approaches, Brutchey's group [26] developed an alkanethiol-alkylamine solvent mixture to dissolve $\mathrm{V}_{2} \mathrm{VI}_{3}$ chalcogenides (where $\mathrm{V}=\mathrm{As}, \mathrm{Sb}, \mathrm{Bi}$ and $\mathrm{VI}=\mathrm{S}, \mathrm{Se}, \mathrm{Te}$ ). Further studies found that elemental metals [27] and metal oxides [28] with selenium and tellurium could also be dissolved by similar method.

On the other hand, metal oxide/hydroxide precursors are highly desirable because they are the most accessible materials from nature. To dissolve metal oxide for sulfide synthesis, Pan's group [29,30] developed a binary thiolamine mixed solvent. In this reaction system, metalorganic complex containing thiol is formed, which serves as sulfur source. This method has made great success in the synthesis of metal sulfides, but the dissolution selenium and direct synthesis of selenide or selenosulfide are rarely observed. For instance, metal selenide (such as $\mathrm{Cu}_{2} \mathrm{ZnSnSe}_{4}$ ) has to be synthesized by post-selenization [31]. Actually, the direct deposition of selenide is a challenge since selenium is nearly insoluble in common solvent. Therefore, establishing a well-controlled method for the direct deposition of metal selenides is urgent to explore new application with solution processed MCs.

Herein, a new solvent system composed of 2mercaptoethanol (2-ME) and monoethanolamine (MEA) is used to dissolve ten kinds of metal oxide or hydroxide powders and recover a large number of metal chalcogenides. It can also dissolve thiourea and selenium concurrently or separately. This characteristic allows versatile preparation of metal sulfide, selenide or selenosulfide. By varying thiourea and selenium ratio in precursor solutions, we are able to control S/Se atomic ratios in the final MC films. Importantly, the derived MC film can generate photovoltaic effect in a complete working device.

Specifically, the precursor inks were prepared by dissolving metal oxides and/or hydroxides, including $\mathrm{Cu}_{2} \mathrm{O}, \mathrm{ZnO}, \mathrm{SnO}, \mathrm{In}(\mathrm{OH})_{3}, \mathrm{GeO}_{2}, \mathrm{Cd}(\mathrm{OH})_{2}, \mathrm{MnO}, \mathrm{PbO}$, $\mathrm{Bi}_{2} \mathrm{O}_{3}, \mathrm{Sb}_{2} \mathrm{O}_{3}$, in a mixture of 2-ME and MEA with a volume ratio of $1: 3$. For the synthesis of sulfide, selenide or selenosulfide, corresponding thiourea, selenium or thiourea/selenium mixture with stoichiometry are introduced. $\mathrm{ZnO}, \mathrm{MnO}, \mathrm{PbO}, \mathrm{Bi}_{2} \mathrm{O}_{3}, \mathrm{Sb}_{2} \mathrm{O}_{3}$ are quickly dissolved in the mixture solvent at room temperature. Nonetheless, a mild heating at $60^{\circ} \mathrm{C}$ is required for fast dissolution of $\mathrm{Cu}_{2} \mathrm{O}, \mathrm{SnO}, \mathrm{In}(\mathrm{OH})_{3}, \mathrm{GeO}_{2}$ and $\mathrm{Cd}(\mathrm{OH})_{2}$. The resulting compound inks are all homogenous without visible light scattering (Fig. 1) and remain stable for periods ranging from days to months under ambient conditions, promising in scalable and practical applications.

The formation of MCs was conducted by thermal

CAS Key Laboratory of Materials for Energy Conversion, Department of Materials Science and Engineering, University of Science and Technology of China, Hefei 230026, China

* Corresponding authors (emails: cfzhu@ustc.edu.cn (Zhu C); tchenmse@ustc.edu.cn (Chen T)) 


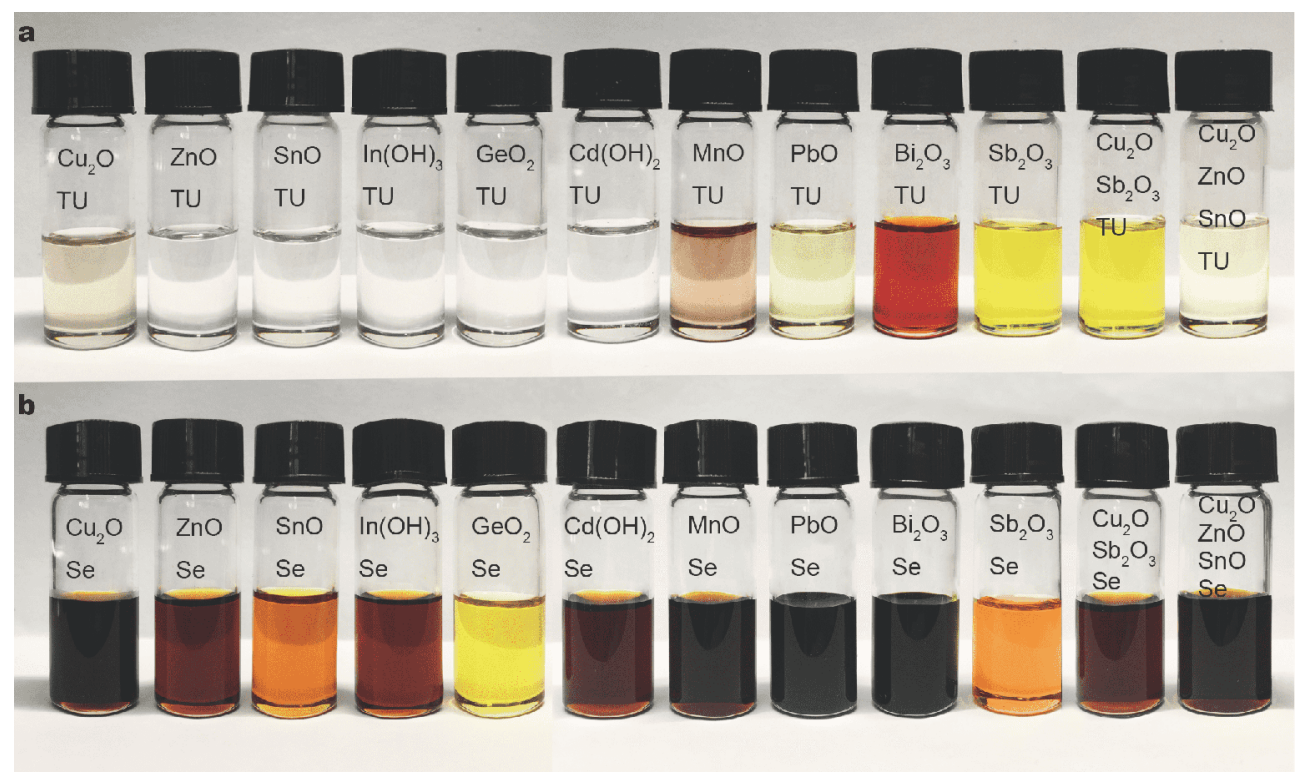

Figure 1 Photographs of metal oxides (hydroxides) dissolving in 2-ME and MEA. (a) Photographs of $\mathrm{Cu}_{2} \mathrm{O}, \mathrm{ZnO}, \mathrm{SnO}, \mathrm{In}(\mathrm{OH})_{3}, \mathrm{GeO}{ }_{2}, \mathrm{Cd}(\mathrm{OH})_{2}$, $\mathrm{MnO}, \mathrm{PbO}, \mathrm{Bi}_{2} \mathrm{O}_{3}, \mathrm{Sb}_{2} \mathrm{O}_{3}$, binary $\mathrm{Cu}_{2} \mathrm{O}$ and $\mathrm{Sb}_{2} \mathrm{O}_{3}$, ternary $\mathrm{Cu}_{2} \mathrm{O}, \mathrm{ZnO}$ and $\mathrm{SnO}$ in the mixded solution with thiourea (a) and $\mathrm{Se}$ (b), respectively.

decomposition of the precursor inks under $\mathrm{N}_{2}$ atmosphere. Upon annealing at $280-400^{\circ} \mathrm{C}$, binary metal sulfides $\mathrm{ZnS}, \mathrm{SnS}, \mathrm{CdS}, \mathrm{MnS}, \mathrm{PbS}, \mathrm{Bi}_{2} \mathrm{~S}_{3}, \mathrm{Sb}_{2} \mathrm{~S}_{3}$ are obtained from the corresponding metal oxide precursor inks. X-ray diffraction (XRD) patterns indicate phase pure metal sulfides (Fig. 2a, Fig. S1), and the detailed peak assignment for each of the compounds is in Supplementary information. It is worth noting that the synthesis in absence of thiourea would not produce sulfide, indicating that the thiourea provides sulfur source [32]. The synthesis of metal selenide was conducted in a similar way to sulfide by substituting thiourea with selenium
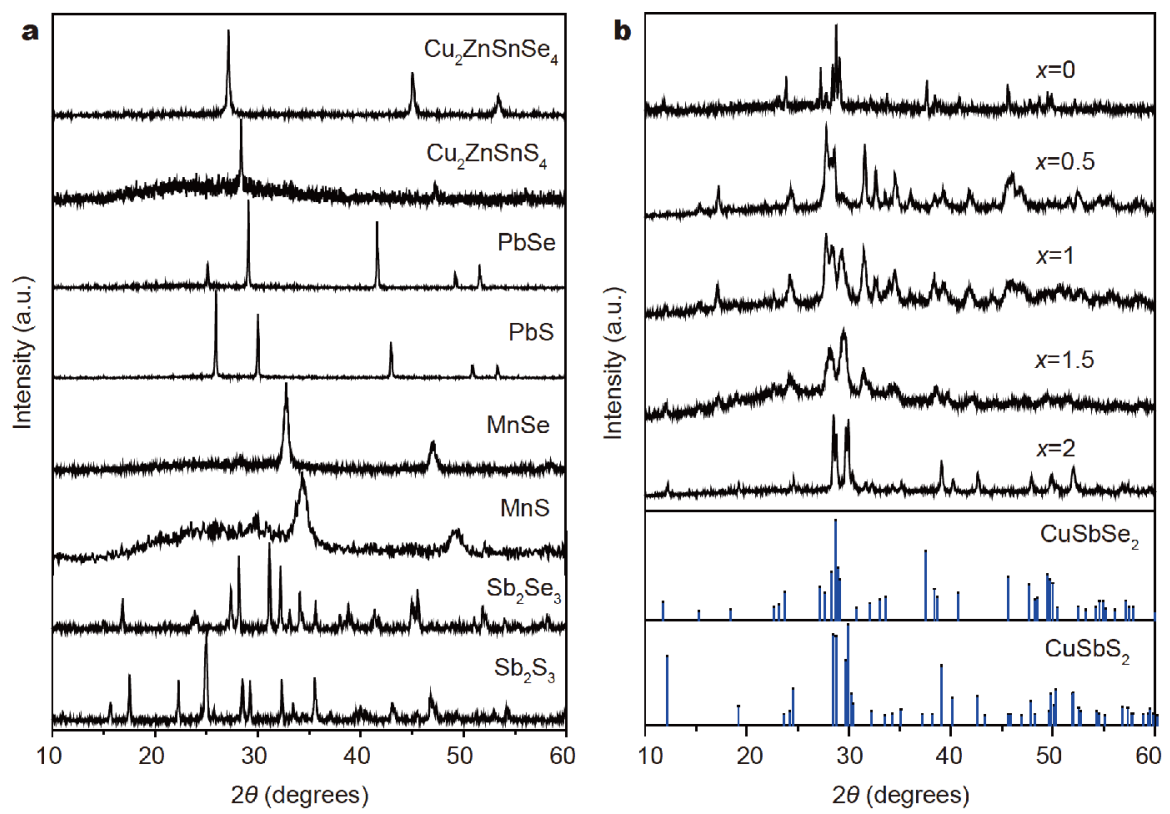

Figure $2 \mathrm{XRD}$ characterizations of the as-generated metal chalcogenides films from the solution. (a) XRD patterns of $\mathrm{Sb}_{2} \mathrm{~S}_{3}, \mathrm{Sb}_{2} \mathrm{Se}_{3}, \mathrm{MnS}_{\mathrm{MnSe}}, \mathrm{PbS}$, $\mathrm{PbSe}, \mathrm{Cu}_{2} \mathrm{ZnSnS}_{4}, \mathrm{Cu}_{2} \mathrm{ZnSnSe}_{4}$. (b) XRD patterns of CuSbSe ${ }_{2-x} \mathrm{~S}_{x}$ alloys, where $x=2.0,1.5,1.0,0.5$ and 0. 
power. Phase-pure crystalline selenides including $\mathrm{Cu}_{2} \mathrm{Se}$, $\mathrm{ZnSe}, \mathrm{In}_{2} \mathrm{Se}_{3}, \mathrm{CdSe}, \mathrm{MnSe}, \mathrm{PbSe}, \mathrm{Sb}_{2} \mathrm{Se}_{3}$ are generated from the corresponding precursor inks after thermal decomposition at $300-400^{\circ} \mathrm{C}$ (Fig. 2a, Fig. S2).

This method is capable to synthesize ternary $\mathrm{CuSbS}_{2}$, $\mathrm{CuSbSe}_{2}, \mathrm{Cu}_{2} \mathrm{SnS}_{3}$ and quaternary $\mathrm{Cu}_{2} \mathrm{ZnSnS}_{4}, \mathrm{Cu}_{2}$ $\mathrm{ZnSnSe}_{4}$ (Fig. S3). Moreover, by tuning selenium ratio in the reaction precursors, the band gap of the metal chalcogenide can be conveniently tuned. Recently, it has been discovered that $\mathrm{CuSbSe}_{2-x} \mathrm{~S}_{x}$ is a promising light absorbing material with direct band gap energy $E_{\mathrm{g}}$ $=0.91-1.89 \mathrm{eV}$ and high absorption coefficient [33-35], while there has been no report on the solution processed $\mathrm{CuSbSe}_{2-x} \mathrm{~S}_{x}$ with tunable band gap. Herein, we synthesize the composition/band gap tunable $\mathrm{CuSbSe}_{2-x} \mathrm{~S}_{x}$ with the aforementioned method. $\mathrm{Cu}_{2} \mathrm{O}$ and $\mathrm{Sb}_{2} \mathrm{O}_{3}$ were applied as copper and antimony sources which were dissolved in the mixed solvent. The composition was tuned by varying metal/Se stoichiometric ratios (EXPERIMENTAL SECTION in SI). The spin coated precursor solution was then annealed at $390^{\circ} \mathrm{C}$ for $3 \mathrm{~min}$. Fig. $2 \mathrm{~b}$ shows the XRD patterns of the as-generated $\mathrm{CuSbSe}_{2-x} \mathrm{~S}_{x}$ alloys (nominal $x=2,1.5,1,0.5,0)$ are crystalline. With the increase of Se content in $\mathrm{CuSbSe}_{2-x} \mathrm{~S}_{x}$, the XRD patterns display gradual shift to lower diffraction angle, which is attributed to the larger anionic radius of $\mathrm{Se}^{2-}$ than $\mathrm{S}^{2-}$ (Shannon-Prewitt anionic radii of $\mathrm{S}^{2-}$ and $\mathrm{Se}^{2-}$ are 1.84 and $1.98 \AA$, [36] respectively). Raman spectroscopy (Fig. S4) of $\mathrm{CuSbS}_{2}$ and $\mathrm{CuSbSe}_{2}$ show distinctive peaks located at $333 \mathrm{~cm}^{-1}$ for $\mathrm{CuSbS}_{2}$ and at $114,152,197,226 \mathrm{~cm}^{-1}$ for $\mathrm{CuSbSe}_{2}$, exhibiting phase pure $\mathrm{CuSb}(\mathrm{S}, \mathrm{Se})_{2}$ [34,37]. The final composition of $\mathrm{CuSbSe}_{2-x} \mathrm{~S}_{x}$ is determined by energydispersive X-ray spectroscopy (EDS) analysis (Table S1), and they are thus described as $\mathrm{CuSbS}_{2}, \mathrm{CuSbSe}_{0.4} \mathrm{~S}_{1.6}$, $\mathrm{CuSbSe}_{0.88} \mathrm{~S}_{1.12}, \mathrm{CuSbSe}_{1.32} \mathrm{~S}_{0.68}$ and $\mathrm{CuSbSe}_{1.92} \mathrm{~S}_{0.08}$ with nominal $x=2,1.5,1,0.5,0$. The actual elemental composition of each compound generally matches the nominal element ratio in the precursors. According to the UV-vis spectra and Tauc plots, the corresponding band gap energies of them are determined to be 1.31, 1.29, 1.24, $1.17,1.08 \mathrm{eV}$ (Fig. 3a). The dependence of $E_{\mathrm{g}}$ on composition (Fig. 3b) was found to slightly deviate from Vegard's law. This result indicates that it is convenient to manipulate the composition and then the band gap of MCs by the current method.

Synthesis of quaternary metal chalcogenide with controllable phase and stoichiometry remains a challenge. Our method is also applicable for the direct synthesis of phase pure $\mathrm{Cu}_{2} \mathrm{ZnSn}(\mathrm{S}, \mathrm{Se})_{4}$ (CZTSSe). CZTSSe has emerged as an ideal light-absorbing material for new
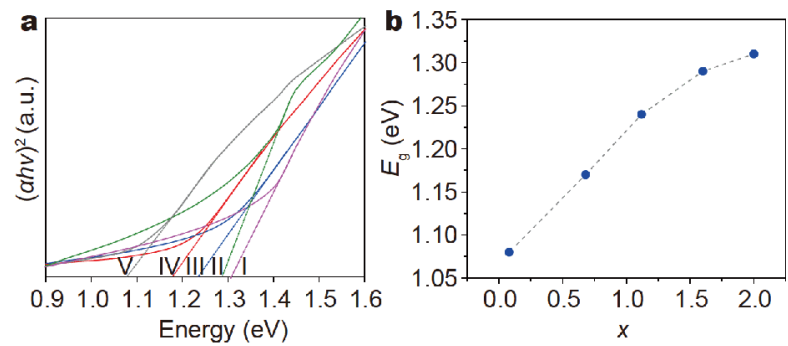

Figure 3 (a) Tauc plots showing band gap tunablity of $\mathrm{CuSbS}_{2}$ (I), $\mathrm{CuSbSe}_{0.4} \mathrm{~S}_{1.6} \quad$ (II), $\quad \mathrm{CuSbSe}_{0.88} \mathrm{~S}_{1.12} \quad$ (III), $\mathrm{CuSbSe}_{1.32} \mathrm{~S}_{0.68}$ (IV) and CuSbSe $_{1.92} \mathrm{~S}_{0.08}(\mathrm{~V})$ measured by UV-vis spectroscopy, exhibiting direct band gaps of 1.31, 1.29, 1.24, 1.17, $1.08 \mathrm{eV}$ for $\mathrm{CuSbS}_{2}, \mathrm{CuSbSe}_{0.4} \mathrm{~S}_{1.6}$, $\mathrm{CuSbSe}_{0.88} \mathrm{~S}_{1.12}, \mathrm{CuSbSe}_{1.32} \mathrm{~S}_{0.68}$ and $\mathrm{CuSbSe}_{1.92} \mathrm{~S}_{0.08}$, respectively. (b) The relationship between $x$ and band gap $\left(E_{\mathrm{g}}\right)$ of $\mathrm{CuSbSe}_{2-x} \mathrm{~S}_{x}$ alloys.

generation thin film solar cells due to its suitable band gap and high absorption coefficient [38-40]. Here we fabricated high quality pure selenide CZTSe thin film by dissolving stoichiometric amounts of $\mathrm{Cu}_{2} \mathrm{O}, \mathrm{ZnO}, \mathrm{SnO}$ and Se (EXPERIMENTAL SECTION in SI). In Fig. 2a, the XRD pattern of the as-realized CZTSe thin film shows the strong diffraction at $27.16^{\circ}, 45.12^{\circ}$ and $53.39^{\circ}$ assigned to (112), (220) and (312) crystal planes of kesterite structure (JCPDS No. 52-0868). Raman spectroscopy identifies whether there is potential binary and ternary secondary phases, such as $\mathrm{Cu}_{x} \mathrm{Se}, \mathrm{ZnSe}$ and $\mathrm{Cu}_{2} \mathrm{SnSe}_{3}$, since they exhibit indistinguishable XRD patterns compared with CZTSe. Three peaks located at 174, 196, and $234 \mathrm{~cm}^{-1}$ (Fig. S5) are typical Raman scattering of CZTSe kesterite phase [41]. There are no peaks at 260, 253 and $180 \mathrm{~cm}^{-1}$ for $\mathrm{Cu}_{x} \mathrm{Se}, \mathrm{ZnSe}$ and $\mathrm{Cu}_{2} \mathrm{SnSe}_{3}$ [42], indicating that our method is able to directly synthesize phase purity CZTSe film. Furthermore, X-ray photoelectron spectroscopy (Fig. S6) indicates that $\mathrm{Cu} 2 \mathrm{p}$ peaks located at 932.1 and $951.9 \mathrm{eV}$ with a splitting value of $19.8 \mathrm{eV}$ (Fig. S7a), corresponding to $\mathrm{Cu}^{+}$rather than $\mathrm{Cu}^{2+}$ [43]. EDS was employed to determine the chemical composition (Table S2). The ratio of $\mathrm{Cu} /(\mathrm{Zn}+\mathrm{Sn})$ is 0.83 and $\mathrm{Zn} / \mathrm{Sn}$ is 1.10 , which falls into the optimum compositional ratio region (i.e., $\mathrm{Cu} /(\mathrm{Zn}+\mathrm{Sn})$ and $\mathrm{Zn} / \mathrm{Sn}$ are $0.75-0.95$ and 1.1-1.4) [44], conforming to the criteria of $\mathrm{Cu}$-poor and $\mathrm{Zn}$-rich for high performance kesterite solar cell. The morphological characterizations of the assynthesized film are provided in Fig. S7.

Finally, we investigated the dissolution process and applied $\mathrm{Sb}_{2} \mathrm{~S}_{3}$ in solar cell. 2-ME and MEA solvent mixture with volume ratio of 1:3.2 was applied to dissolve $\mathrm{Sb}_{2} \mathrm{O}_{3}$ (EXPERIMENTAL DETAILS in SI). The solution was stirred for $30 \mathrm{~min}$ at ambient condition to obtain a 
homogenous solution. The dissolution reaction was firstly analyzed by Fourier transform infrared spectroscopy (FTIR) and the Raman spectroscopy (Fig. S8). After $\mathrm{Sb}_{2} \mathrm{O}_{3}$ was introduced into the solvent mixture of 2-ME $\left(\mathrm{C}_{2} \mathrm{H}_{6} \mathrm{OS}\right)$ and MEA $\left(\mathrm{C}_{2} \mathrm{H}_{7} \mathrm{NO}\right)$, $v_{\mathrm{S}-\mathrm{H}}$ stretch at $2,550 \mathrm{~cm}^{-1}$ disappeared (Fig. S8a), indicating the deprotonation of $\mathrm{S}-\mathrm{H}$, which is evidenced by Raman spectra (Fig. S8b). The peak located at $284 \mathrm{~cm}^{-1}$ is typical Raman scattering of $\mathrm{Sb}-\mathrm{S}$ bonding. Moreover, the peak at $332 \mathrm{~cm}^{-1}$ can be ascribed to $C_{3 \mathrm{v}}$ symmetric modes of $\mathrm{SbS}_{3}$ pyramid structure [45,46], with no peaks at $360-390 \mathrm{~cm}^{-1}$ for $\mathrm{Sb}-\mathrm{N}$ stretching vibration [47]. Therefore, the total dissolution reaction can be described as follow:

$$
\begin{aligned}
& \mathrm{Sb}_{2} \mathrm{O}_{3}+6 \mathrm{C}_{2} \mathrm{H}_{6} \mathrm{OS}+3 \mathrm{C}_{2} \mathrm{H}_{7} \mathrm{NO} \rightarrow \\
& 2\left[\mathrm{Sb}\left(\mathrm{C}_{2} \mathrm{H}_{5} \mathrm{OS}\right)_{3}\right]+3 \mathrm{C}_{2} \mathrm{H}_{8} \mathrm{NO}^{+}+3 \mathrm{OH}^{-} .
\end{aligned}
$$

Different from many reports in literature $[48,49]$, we need introduce another sulfur source to fabricate metal sulfides in this particular solvent mixture, herein, the thiourea. Ultimately, the reaction between this $\mathrm{Sb}$ complex and thiourea can lead to $\mathrm{Sb}_{2} \mathrm{~S}_{3}$. In addition, the dissolution of selenium was studied by Raman spectroscopy. After selenium dissolved in 2-ME and MEA, two bands at 272 and $394 \mathrm{~cm}^{-1}$ are ascribed to selenium rings and S-Se stretching vibration (Fig. S9) [50,51]. Regardless the formation of molecular selenium or S-Se in the solution, the final transformation towards metal selenide or selenosulfide becomes feasible.

Thermogravimetric analysis (TGA) was used to guide the preparation of $\mathrm{Sb}_{2} \mathrm{~S}_{3}$ light absorbing film. The precursor solution displays a weight loss of $89 \mathrm{wt} . \%$ with an ending temperature at $280^{\circ} \mathrm{C}$ (Fig. S10), indicating the formation of $\mathrm{Sb}_{2} \mathrm{~S}_{3}$ when temperature is raised to $280^{\circ} \mathrm{C}$. For device fabrication, the precursor solution was spincoated on the $\mathrm{TiO}_{2}$ compact layer (abbreviated as c- $\mathrm{TiO}_{2}$ ) at $3,000 \mathrm{rpm}$ for $30 \mathrm{~s}$. SEM images show that the asprepared $\mathrm{Sb}_{2} \mathrm{~S}_{3}$ thin film displays compact surface morphology (Fig. 4a). The solar cell was completed by coating a layer of $2,2^{\prime}, 7,7^{\prime}$-tetrakis $(N, N$-di- $p$-methoxyphenylamine)-9,9'-spirobifluorene (spiro-OMeTAD) as hole transporting material, followed by thermal deposition of $\mathrm{Au}$ metal film as back contact according to the reported method [52,53]. The device configuration is thus described as $\mathrm{FTO} / \mathrm{c}-\mathrm{TiO}_{2} / \mathrm{Sb}_{2} \mathrm{~S}_{3} /$ Spiro-OMeTAD/Au (Fig. 4b). A cross sectional SEM image shows that the thicknesses of $\mathrm{Sb}_{2} \mathrm{~S}_{3}$, Spiro-OMeTAD, Au are 134, 150 and $80 \mathrm{~nm}$, respectively. The photocurrent densityvoltage $(J-V)$ spectra were measured under one Sun AM 1.5G irradiation (Fig. 4c). The solar cell delivers a power conversion efficiency (PCE) of $4.39 \%$ with a short-circuit
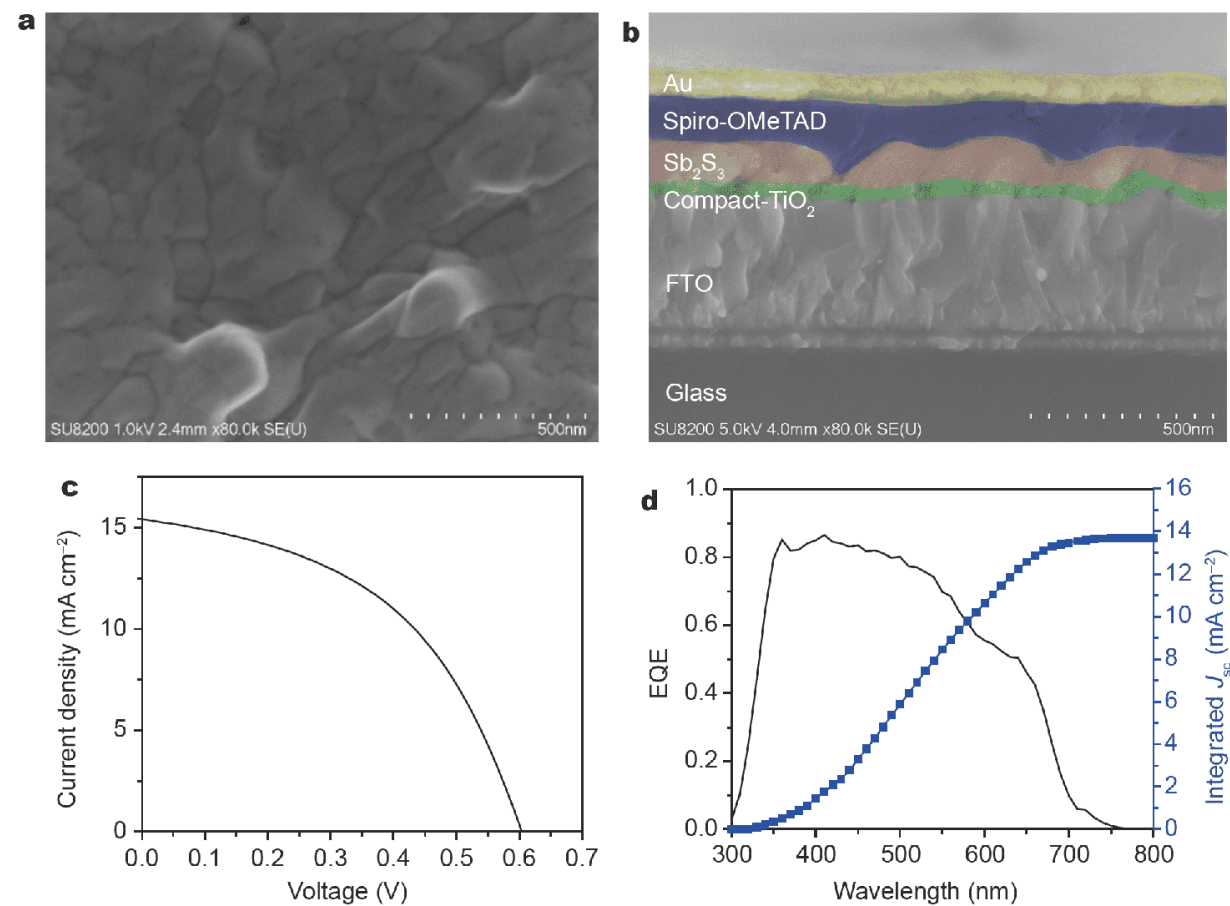

Figure 4 (a) SEM image of as-prepared $\mathrm{Sb}_{2} \mathrm{~S}_{3}$ thin film deposited on $\mathrm{FTO} / \mathrm{c}-\mathrm{TiO}_{2}$ and (b) cross-sectional SEM image of the solar cell device. (c) $J$ - $V$ curve of $\mathrm{Sb}_{2} \mathrm{~S}_{3}$ planar heterojunction solar cell measured under one Sun AM 1.5G illumination. (d) EQE spectrum of the $\mathrm{Sb}_{2} \mathrm{~S}_{3}$ planar heterojunction solar cell. 

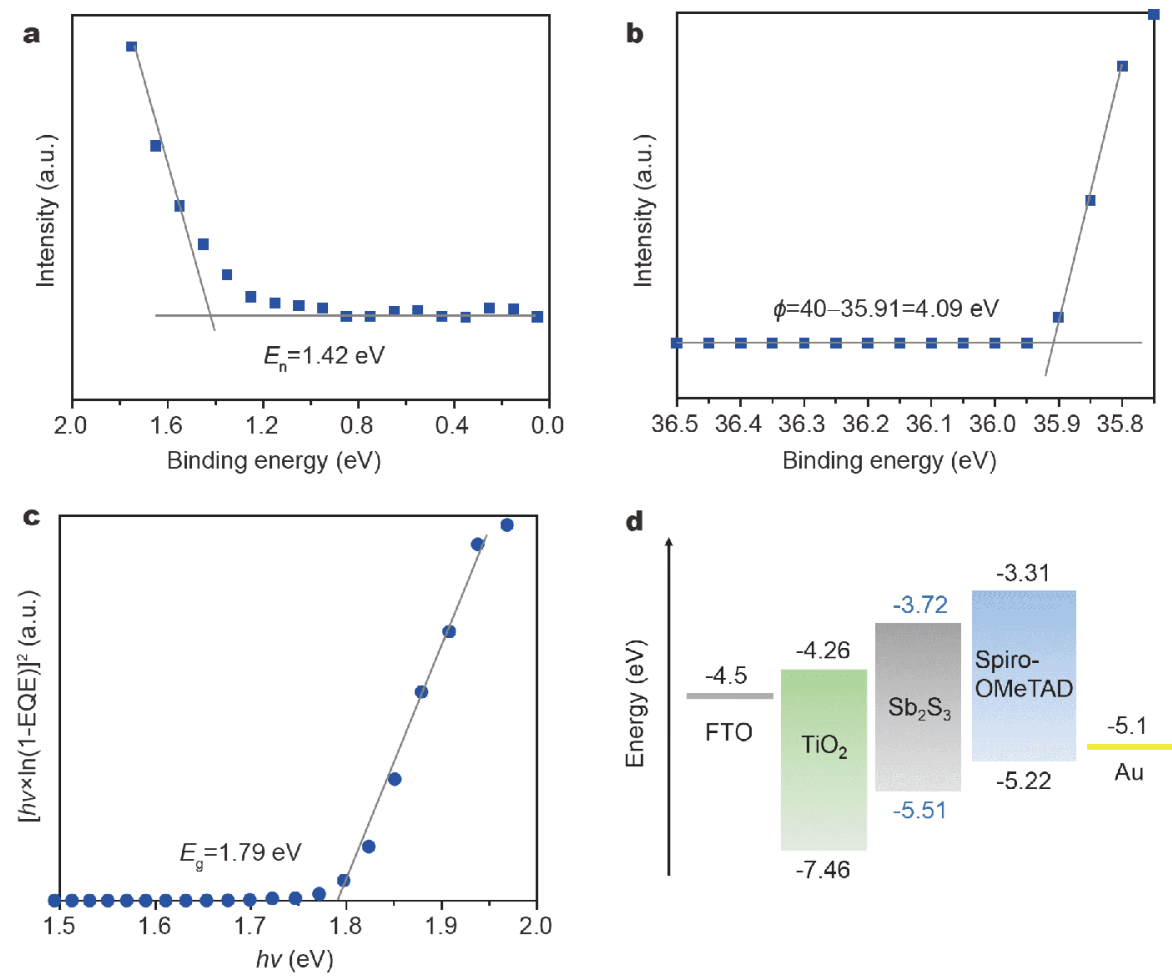

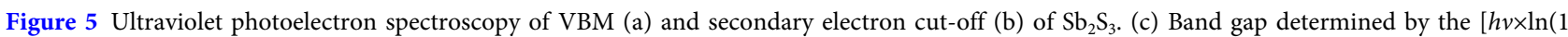
$-\mathrm{EQE})]^{2}$ versus $h v$ curve. (d) Energy level diagram of $\mathrm{FTO} / \mathrm{TiO}_{2} / \mathrm{Sb}_{2} \mathrm{~S}_{3} /$ spiro-OMeTAD/Au.

current density $\left(J_{\mathrm{sc}}\right)$ of $15.39 \mathrm{~mA} \mathrm{~cm}{ }^{-2}$, open-circuit voltage $\left(V_{\text {oc }}\right)$ of $0.599 \mathrm{~V}$, and fill factor (FF) of $47.62 \%$, respectively. In fact, during our investigations we tried other amine such as $n$-butylamine, $n$-propylamine, and 1 , 2-ethylenediamine to substitute for monoethanolamine. However, the device efficiency becomes quite poor. The relatively high and similar boiling point of monoethanolamine with 2-ME enables the solvent dissociation at a temperature close to their boiling points. In this manner, the electric property of the film could be improved and thus the device efficiency is enhanced. Fig. $4 \mathrm{~d}$ presents the external quantum efficiency (EQE) spectrum of the corresponding solar cell, which shows a strong response of above $80 \%$ in the wavelength range from 360 to $500 \mathrm{~nm}$, indicating a high photocurrent conversion collection efficiency. The integrated current density of device is $13.68 \mathrm{~mA} \mathrm{~cm}^{-2}$, which is quite close to the value obtained from $J-V$ measurement $\left(15.39 \mathrm{~mA} \mathrm{~cm}{ }^{-2}\right)$. The energy level of as-synthesized $\mathrm{Sb}_{2} \mathrm{~S}_{3}$ film is characterized by synchrotron-based high resolution ultraviolet photoelectron spectroscopy (Fig. 5), which shows both valence band maximum (VBM, Fig. 5a) and secondary electron cut-off (Fig. 5b) of $\mathrm{Sb}_{2} \mathrm{~S}_{3}$. The VBM is $1.42 \mathrm{eV}$ below the
Fermi level, and the work function $(\phi)$, defined as the difference between vacuum level and Fermi level, is $4.09 \mathrm{eV}$ for $\mathrm{Sb}_{2} \mathrm{~S}_{3}$. We can calculate the conduction band minimum by considering the band gap of as-fabricated $\mathrm{Sb}_{2} \mathrm{~S}_{3}$ of $1.79 \mathrm{eV}$ determined by plotting $[h v \times \ln (1-\mathrm{EQE})]^{2}$ versus $h v$ (Fig. $5 \mathrm{c}$ ), which is consistent with the value acquired from UV-vis absorption (Fig. S13) and the reported $E_{\mathrm{g}}$ value in literature [54-56]. Finally, the band alignment of the solar cell in Fig. $5 \mathrm{~d}$ shows that the electron can transfer from the conduction band of $\mathrm{Sb}_{2} \mathrm{~S}_{3}$ to $\mathrm{c}-\mathrm{TiO}_{2}$ and hole is able to transfer from the valence band of $\mathrm{Sb}_{2} \mathrm{~S}_{3}$ to spiro-OMeTAD. In addition, the device based on as-obtained $\mathrm{Sb}_{2} \mathrm{Se}_{3}$ film was also prepared. With a rough optimization, it generates a PCE of $1.77 \%$, with $J_{\mathrm{sc}}$ of $11.37 \mathrm{~mA} \mathrm{~cm}^{-2}, V_{\text {oc }}$ of $0.364 \mathrm{~V}$ and $\mathrm{FF}$ of $42.97 \%$ (Fig. S14). The active area of the device was defined at $0.12 \mathrm{~cm}^{2}$. This performance is slightly lower than the hydrazine derived $\mathrm{Sb}_{2} \mathrm{Se}_{3}$ film for planar heterojunction solar cells [57].

In summary, a low-toxic, versatile binary solution of 2-ME and MEA was used to fabricate metal chalcogenides. Mechanistic investigations shows that the deprotonation of $-\mathrm{SH}$ is responsible for the dissolution of metal 
oxide or hydroxide. The successful dissolution of thiourea and selenium allows convenient tuning of the S/Se ratio in the final products. With that, binary crystalline metal chalcogenides including $\mathrm{ZnS}, \mathrm{SnS}, \mathrm{CdS}, \mathrm{MnS}, \mathrm{PbS}, \mathrm{Bi}_{2} \mathrm{~S}_{3}$, $\mathrm{Sb}_{2} \mathrm{~S}_{3}, \mathrm{Cu}_{2} \mathrm{Se}, \mathrm{ZnSe}, \mathrm{In}_{2} \mathrm{Se}_{3}, \mathrm{CdSe}, \mathrm{MnSe}, \mathrm{PbSe}, \mathrm{Sb}_{2} \mathrm{Se}_{3}$, ternary $\mathrm{CuSbS}_{2}, \mathrm{CuSbSe}_{2}, \mathrm{Cu}_{2} \mathrm{SnS}_{3}$ and quaternary $\mathrm{Cu}_{2}$ $\mathrm{ZnSnS}_{4}, \mathrm{Cu}_{2} \mathrm{ZnSnSe}_{4}$ have been successfully prepared. Band gap tunable CuSbSe $e_{2-x} \mathrm{~S}_{x}$ was illustrated by varying precursor ratios. The implement in solar cell application is also demonstrated by using the as-prepared $\mathrm{Sb}_{2} \mathrm{~S}_{3}$ film, indicating this approach is able to generate device grade films.

\section{Received 12 October 2018; accepted 20 November 2018; published online 30 November 2018}

1 Wang $\mathrm{H}$, Liang $\mathrm{Y}, \mathrm{Li} \mathrm{Y}$, et al. $\mathrm{Co}_{1-x} \mathrm{~S}$-graphene hybrid: a highperformance metal chalcogenide electrocatalyst for oxygen reduction. Angew Chem Int Ed, 2011, 50: 10969-10972

2 Zhang R, Cho S, Lim DG, et al. Metal-metal chalcogenide molecular precursors to binary, ternary, and quaternary metal chalcogenide thin films for electronic devices. Chem Commun, 2016, 52: 5007-5010

3 Wang RY, Feser JP, Gu X, et al. Universal and solution-processable precursor to bismuth chalcogenide thermoelectrics. Chem Mater, 2010, 22: 1943-1945

4 Bottner H, Nurnus J, Gavrikov A, et al. New thermoelectric components using microsystem technologies. J Microelectromech Syst, 2004, 13: 414-420

5 Milliron DJ, Raoux S, Shelby RM, et al. Solution-phase deposition and nanopatterning of GeSbSe phase-change materials. Nat Mater, 2007, 6: 352-356

6 Ohta T. Phase-change optical memory promotes the dvd optical disk. J Optoelectron Adv Mater, 2001, 3: 609-626

7 Ohta T. Quick-set thin films. Nature, 2004, 428: 269-271

8 Milliron DJ, Mitzi DB, Copel M, et al. Solution-processed metal chalcogenide films for p-type transistors. Chem Mater, 2006, 18: $587-590$

9 Choi YC, Lee $\mathrm{YH}, \mathrm{Im} \mathrm{SH}$, et al. Efficient inorganic-organic heterojunction solar cells employing $\mathrm{Sb}_{2}\left(\mathrm{~S}_{x} / \mathrm{Se}_{1-x}\right)_{3}$ graded-composition sensitizers. Adv Energy Mater, 2014, 4: 1301680

10 Bag S, Gunawan O, Gokmen T, et al. Low band gap liquidprocessed CZTSe solar cell with $10.1 \%$ efficiency. Energy Environ Sci, 2012, 5: 7060-7065

11 Mitzi DB, Gunawan O, Todorov TK, et al. The path towards a high-performance solution-processed kesterite solar cell. Sol Energy Mater Sol Cells, 2011, 95: 1421-1436

12 Todorov TK, Reuter KB, Mitzi DB. high-efficiency solar cell with earth-abundant liquid-processed absorber. Adv Mater, 2010, 22: E156-E159

13 Kronik L, Cahen D, Schock HW. Effects of sodium on polycrystalline $\mathrm{Cu}(\mathrm{In}, \mathrm{Ga}) \mathrm{Se}_{2}$ and its solar cell performance. Adv Mater, 1998, 10: 31-36

14 Zhang R, Szczepaniak SM, Carter NJ, et al. A versatile solution route to efficient $\mathrm{Cu}_{2} \mathrm{ZnSn}(\mathrm{S}, \mathrm{Se})_{4}$ thin-film solar cells. Chem Mater, 2015, 27: 2114-2120

15 Zhao D, Tian Q, Zhou Z, et al. Solution-deposited pure selenide
CIGSe solar cells from elemental Cu, In, Ga, and Se. J Mater Chem A, 2015, 3: 19263-19267

16 Zhao X, Lu M, Koeper MJ, et al. Solution-processed sulfur depleted $\mathrm{Cu}(\mathrm{In}, \mathrm{Ga}) \mathrm{Se}_{2}$ solar cells synthesized from a monoamine-dithiol solvent mixture. J Mater Chem A, 2016, 4: 7390-7397

17 Graetzel M, Janssen RAJ, Mitzi DB, et al. Materials interface engineering for solution-processed photovoltaics. Nature, 2012, 488: $304-312$

18 Sun Y, Welch GC, Leong WL, et al. Solution-processed smallmolecule solar cells with 6.7\% efficiency. Nat Mater, 2012, 11: 4448

19 Xiao Z, Bi C, Shao Y, et al. Efficient, high yield perovskite photovoltaic devices grown by interdiffusion of solution-processed precursor stacking layers. Energy Environ Sci, 2014, 7: 2619-2623

20 Mitzi DB, Kosbar LL, Murray CE, et al. High-mobility ultrathin semiconducting films prepared by spin coating. Nature, 2004, 428: 299-303

21 Mitzi DB. Solution processing of chalcogenide semiconductors via dimensional reduction. Adv Mater, 2009, 21: 3141-3158

22 Yuan M, Mitzi DB. Solvent properties of hydrazine in the preparation of metal chalcogenide bulk materials and films. Dalton Trans, 2009, 13: 6078

23 Mitzi DB. Solution-processed inorganic semiconductors. J Mater Chem, 2004, 14: 2355-2365

24 Mitzi DB, Yuan M, Liu W, et al. A high-efficiency solutiondeposited thin-film photovoltaic device. Adv Mater, 2008, 20: 3657-3662

25 Todorov TK, Gunawan O, Gokmen T, et al. Solution-processed Cu $(\mathrm{In}, \mathrm{Ga})(\mathrm{S}, \mathrm{Se})_{2}$ absorber yielding a $15.2 \%$ efficient solar cell. Prog Photovolt-Res Appl, 2013, 21: 82-87

26 Webber DH, Brutchey RL. Alkahest for $\mathrm{V}_{2} \mathrm{VI}_{3}$ chalcogenides: dissolution of nine bulk semiconductors in a diamine-dithiol solvent mixture. J Am Chem Soc, 2013, 135: 15722-15725

27 Webber DH, Buckley JJ, Antunez PD, et al. Facile dissolution of selenium and tellurium in a thiol-amine solvent mixture under ambient conditions. Chem Sci, 2014, 5: 2498-2502

28 McCarthy CL, Webber DH, Schueller EC, et al. Solution-phase conversion of bulk metal oxides to metal chalcogenides using a simple thiol-amine solvent mixture. Angew Chem Int Ed, 2015, 54: 8378-8381

29 Tian Q, Wang G, Zhao W, et al. Versatile and low-toxic solution approach to binary, ternary, and quaternary metal sulfide thin films and its application in $\mathrm{Cu}_{2} \mathrm{ZnSn}(\mathrm{S}, \mathrm{Se})_{4}$ solar cells. Chem Mater, 2014, 26: 3098-3103

30 Wang G, Wang S, Cui Y, et al. A novel and versatile strategy to prepare metal-organic molecular precursor solutions and its application in $\mathrm{Cu}(\mathrm{In}, \mathrm{Ga})(\mathrm{S}, \mathrm{Se})_{2}$ solar cells. Chem Mater, 2012, 24: 3993-3997

31 Yang $\mathrm{Y}$, Wang G, Zhao W, et al. Solution-processed highly efficient $\mathrm{Cu}_{2} \mathrm{ZnSnSe}_{4}$ thin film solar cells by dissolution of elemental $\mathrm{Cu}, \mathrm{Zn}, \mathrm{Sn}$, and Se powders. ACS Appl Mater Interfaces, 2015, 7: 460-464

32 Choi YC, Seok SI. Efficient $\mathrm{Sb}_{2} \mathrm{~S}_{3}$-sensitized solar cells via singlestep deposition of $\mathrm{Sb}_{2} \mathrm{~S}_{3}$ using $\mathrm{S} / \mathrm{Sb}$-ratio-controlled $\mathrm{SbCl}_{3}$-thiourea complex solution. Adv Funct Mater, 2015, 25: 2892-2898

33 Kumar M, Persson C. $\mathrm{CuSbS}_{2}$ and $\mathrm{CuBiS}_{2}$ as potential absorber materials for thin-film solar cells. J Renew Sustain Energy, 2013, 5: 031616

34 Xue DJ, Yang B, Yuan ZK, et al. $\mathrm{CuSbSe}_{2}$ as a potential photovoltaic absorber material: studies from theory to experiment. 
Adv Energy Mater, 2015, 5: 1501203

35 Choi YC, Yeom EJ, Ahn TK, et al. $\mathrm{CuSbS}_{2}$-sensitized inorganicorganic heterojunction solar cells fabricated using a metal-thiourea complex solution. Angew Chem Int Ed, 2015, 54: 4005-4009

36 Ladd MFC. Symmetry of crystals and molecules. Oxford: Oxford University Press, 2014

37 McCarthy CL, Cottingham P, Abuyen K, et al. Earth abundant $\mathrm{CuSbS}_{2}$ thin films solution processed from thiol-amine mixtures. J Mater Chem C, 2016, 4: 6230-6233

38 Azimi H, Hou Y, Brabec CJ. Towards low-cost, environmentally friendly printed chalcopyrite and kesterite solar cells. Energy Environ Sci, 2014, 7: 1829-1849

39 Polizzotti A, Repins IL, Noufi R, et al. The state and future prospects of kesterite photovoltaics. Energy Environ Sci, 2013, 6: 3171-3182

40 Zhou H, Hsu WC, Duan HS, et al. CZTS nanocrystals: A promising approach for next generation thin film photovoltaics. Energy Environ Sci, 2013, 6: 2822-2838

41 Redinger A, Hönes K, Fontané X, et al. Detection of a ZnSe secondary phase in coevaporated $\mathrm{Cu}_{2} \mathrm{ZnSnSe}_{4}$ thin films. Appl Phys Lett, 2011, 98: 101907

42 Altosaar M, Raudoja J, Timmo K, et al. $\mathrm{Cu}_{2} \mathrm{Zn}_{1-x} \mathrm{Cd}_{x} \mathrm{Sn}\left(\mathrm{Se}_{1-y} \mathrm{~S}_{y}\right)_{4}$ solid solutions as absorber materials for solar cells. Phys Stat Sol (a), 2008, 205: 167-170

43 Shavel A, Arbiol J, Cabot A. Synthesis of quaternary chalcogenide nanocrystals: stannite $\mathrm{Cu}_{2} \mathrm{Zn}_{x} \mathrm{Sn}_{y} \mathrm{Se}_{1+x+2 y}$. J Am Chem Soc, 2010, 132: $4514-4515$

44 Wang G, Zhao W, Cui Y, et al. Fabrication of a $\mathrm{Cu}_{2} \mathrm{ZnSn}(\mathrm{S}, \mathrm{Se})_{4}$ photovoltaic device by a low-toxicity ethanol solution process. ACS Appl Mater Interfaces, 2013, 5: 10042-10047

45 Shaji S, Garcia LV, Loredo SL, et al. Antimony sulfide thin films prepared by laser assisted chemical bath deposition. Appl Surf Sci, 2017, 393: 369-376

46 Medles M, Benramdane N, Bouzidi A, et al. Raman and optical studies of spray pyrolysed $\mathrm{Sb}_{2} \mathrm{~S}_{3}$ thin films. J Optoelectron Adv Mater, 2014, 16: 726-731

47 Haiges R, Vij A, Boatz JA, et al. First structural characterization of binary $\mathrm{As}(\mathrm{III})$ and $\mathrm{Sb}(\mathrm{III})$ azides. Chem Eur J, 2004, 10: 508-517

48 Buckley JJ, McCarthy CL, Del Pilar-Albaladejo J, et al. Dissolution of $\mathrm{Sn}, \mathrm{SnO}$, and $\mathrm{SnS}$ in a thiol-amine solvent mixture: insights into the identity of the molecular solutes for solution-processed SnS. Inorg Chem, 2016, 55: 3175-3180

49 Tian Q, Cui Y, Wang G, et al. A robust and low-cost strategy to prepare $\mathrm{Cu}_{2} \mathrm{ZnSnS}_{4}$ precursor solution and its application in
$\mathrm{Cu}_{2} \mathrm{ZnSn}(\mathrm{S}, \mathrm{Se})_{4}$ solar cells. RSC Adv, 2015, 5: 4184-4190

50 Poborchii VV, Kolobov AV, Caro J, et al. Polarized Raman spectra of selenium species confined in nanochannels of $\mathrm{AlPO}_{4}$ single crystals. Chem Phys Lett, 1997, 280: 17-23

51 Eysel HH, Sunder S. Homonuclear bonds in sulfur-selenium mixed crystals: A Raman spectroscopic study. Inorg Chem, 1979, 18: 2626-2627

52 Zhang Y, Li J, Jiang G, et al. Selenium-graded $\mathrm{Sb}_{2}\left(\mathrm{~S}_{1-x} \mathrm{Se}_{x}\right)_{3}$ for planar heterojunction solar cell delivering a certified power conversion efficiency of 5.71\%. Sol RRL, 2017, 1: 1700017

53 Wang $\mathrm{X}, \mathrm{Li}$ J, Liu W, et al. A fast chemical approach towards $\mathrm{Sb}_{2} \mathrm{~S}_{3}$ film with a large grain size for high-performance planar heterojunction solar cells. Nanoscale, 2017, 9: 3386-3390

54 Kondrotas R, Chen C, Tang J. $\mathrm{Sb}_{2} \mathrm{~S}_{3}$ solar cells. Joule, 2018, 2: 857878

55 Choi YC, Lee DU, Noh JH, et al. Highly improved $\mathrm{Sb}_{2} \mathrm{~S}_{3}$ sensitizedinorganic-organic heterojunction solar cells and quantification of traps by deep-level transient spectroscopy. Adv Funct Mater, 2014, 24: $3587-3592$

56 Wang X, Tang R, Wu C, et al. Development of antimony sulfideselenide $\mathrm{Sb}_{2}(\mathrm{~S}, \mathrm{Se})_{3}$-based solar cells. J Energy Chem, 2018, 27: 713-721

57 Zhou Y, Leng M, Xia Z, et al. Solution-processed antimony selenide heterojunction solar cells. Adv Energy Mater, 2014, 4: 1301846

Acknowledgements This work was supported by the Fundamental Research Funds for the Central Universities (WK2060140023, WK2060140022, CX3430000001 and WK2060140024), the Major/Innovative Program of Development Foundation of Hefei Center for Physical Science and Technology (2016FXZY003), and the National Natural Science Foundation of China (GG2060140085 and CX2310000097).

Author contributions Zhang $\mathrm{T}$ and Zhang L performed the experiments; Zhang T, Zhang L, Yin Y, Jiang C and Li S analyzed the data; Zhang $\mathrm{T}$ wrote the paper with support from Zhu $\mathrm{C}$ and Chen $\mathrm{T}$; all authors contributed to the general discussion.

Conflict of interest The authors declare no conflict of interest.

Supplementary information Supporting data are available in the online version of the paper. 

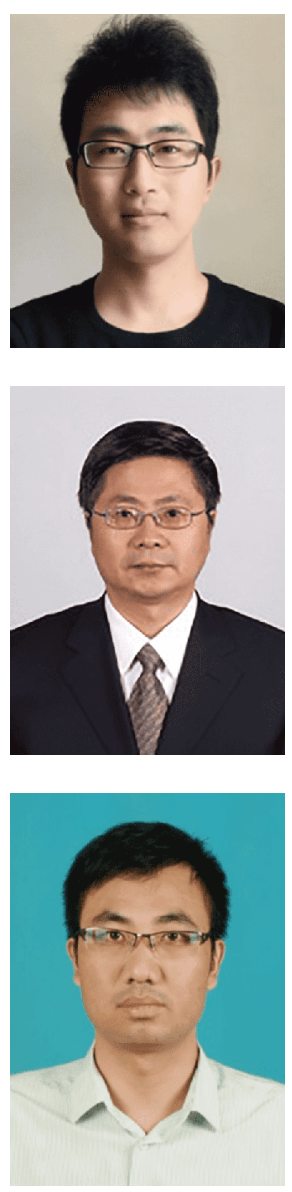

Zhang Tong was born in Hefei, Anhui province (China) in 1993. He received his Bachelor degree from Hefei University of Technology (HFUT) in new energy materials and devices (2015), and now he is pursuing his Master degree in the University of Science and Technology of China (USTC), working on new solar energy materials and solar cells.

Changfei Zhu received his BS and PhD degrees both from USTC in 1984 and 1990, respectively. He has been working in the Department of Materials Science and Engineering of USTC since 1990 and was promoted to full professor in 2000. His research interests include the fundamental study and application of transitional metal oxides, wide band gap semiconductors and thin film solar cells.

Tao Chen received his PhD degree in chemistry from Nanyang Technological University (Singapore) in 2010. From 2011 to 2015, he was working in the Chinese University of Hong Kong as a research assistant professor. He is now a professor at the Department of Materials Science and Engineering, USTC. His research interests include the fabrication and engineering of antimony sulfide-selenide $\left(\mathrm{Sb}_{2}(\mathrm{~S}, \mathrm{Se})_{3}\right)$ solar cells.

\section{一种硫醇/胺方法将金属氧化物转换为器件级金属硫属化物}

张童, 张立建, 尹奕炜, 江晨辉, 李诗昂, 朱长飞, 陈涛 ${ }^{*}$

摘要 利用分子前驱体溶液制备金属硫属化物薄膜在器件领域具有广泛的应用前景. 本文利用颈基乙醇和乙醇胺这种新型硫醇/胺溶剂, 溶解很多价格便宜的金属氧化物和氢氧化物, 如 $\mathrm{Cu}_{2} \mathrm{O}, \mathrm{ZnO}, \mathrm{SnO}, \mathrm{In}(\mathrm{OH})_{3}, \mathrm{GeO}_{2}, \mathrm{Cd}(\mathrm{OH})_{2}, \mathrm{MnO}, \mathrm{PbO}, \mathrm{Bi}_{2} \mathrm{O}_{3}, \mathrm{Sb}_{2} \mathrm{O}_{3}$. 通过添加硫䐖和硒 粉作为硫源和硒源后可以制得相应的二元金属硫化物、硒化物. 此方法还可用来制备纯物相的带隙可调的三元 $\mathrm{CuSbSe} \mathrm{e}_{2-x} \mathrm{~S}_{x}$ 和四元 $\mathrm{Cu}_{2} \mathrm{ZnSnSe}_{4}$. 我们用这种方法合成的 $\mathrm{Sb}_{2} \mathrm{~S}_{3}$ 平面异质结太阳电池光电转化效率可高达到 $4.39 \%$. 这项研究提供了一种制备二元、三元、四 元器件级金属硫属化物薄膜的普适性方法. 